\title{
INDONESIAN WOMEN'S PARTICIPATION IN POLITICS AND GOVERNANCE: CHALLENGES AND OPPORTUNITIES
}

\author{
Astrid Meilasari Sugiana ${ }^{1}$ and Dianingtyas M. Putri ${ }^{1}$ \\ ${ }^{1}$ Universitas Bakrie, Jakarta,Indonesia
}

\begin{abstract}
The number of influential women leaders in Indonesia's public arena has increased significantly in the last ten years. Indonesian women assume leadership in political parties, legislative assembly, national government departments and the judiciary. This paper discusses challenges and best practices which enable Indonesian women to actively and successfully participate in the public sphere both in the political and government arena. This paper is based on the research entitled "Indonesian Women's Participation in Politics" funded by Universitas Bakrie, Jakarta in 2015-2016. Barriers for women's participation in politics and government include lack of resources to finance a campaign or to finance necessities of a successful mandate, public private divide of social space (women as mothers, wives, daughters, daughter in laws), political violence, ideological polarization and patriarchal gender ideology, gender role prescriptions and honor conceptions, sexist and hostile political climate in parliaments and government departments and the lack of psychological empowerment among Indonesian women. Best practices which enable and facilitate women's participation in politics and government in Indonesia include gender mainstreaming through laws and legislations, quotas for women in political parties, parliaments, civil service, judiciaries, executive government departments, sustained and legally supported budgeting for ensuring women's empowerment and participation, grass root social and political empowerment at the local regency level for political recruitment through mentors, regional political party branches and local religious and secular organizations, political education to young girls at schools and universities from the national level to the regional and local levels, diplomacy, negotiating and brokering a form of participative democracy in the context of present political ideologies from subnational to national level politics and governance.
\end{abstract}

Keywords: patriarchal gender ideology, ideological polarization, participative democracy, gender mainstreaming, quotas, political recruitment, diplomacy, brokering

\section{Introduction: Democracy, Diversity and Women in Politics}

A nation in transition, Indonesia is home to 250 million people of diverse social, cultural and political backgrounds. Recent issues involving global financial volatility, global economic disparity, security threats and national disintegration led the Government of Indonesia (GOI) to strengthen its nation's pillars through President Joko Widodo's Nawa Cita Policy in 2015. The primary goal of the policy is to reinforce Indonesia's sovereignty through democracy, inclusive politics, good governance and economic development. Broad strategies that are adopted, among others, include local economic development through the growth of smallmedium enterprises, transformation in socio-political thoughts (i.e. revolusi mental) through citizenship education, public administration reform through e-government and public monitoring, and political socialization and political recruitment through education and decentralized mentoring and gender mainstreaming. Indonesia's need to harbor diversity, democracy and political inclusion stems not from international pressures but rather from the need to diffuse and harness tensions associated with multiculturalism and politics of identity. Multiculturalism and gender mainstreaming are thus perceived as a governmental post ideological strategy to diffuse the tensions of identity politics and its potential to constitute new identities, aiming to keep those struggles within institutionally demarcated limits while producing the culture for recognition. Nonetheless, in Indonesia, multiculturalism and gender mainstreaming can be dangerous since they not only act as cultural 
markers but they also institutionalize and endorse social divisions, producing resentment and alienation in relations between culturally given communities. However, multiculturalism and gender mainstreaming have succeeded best where they have been deployed as conscious governmental strategies that are embedded within the nation's legal, institutional and political framework. Multiculturalism and gender mainstreaming resituate the concept of citizenship in the identity category of community and/or locality, governing through people's allegiance to pre-existing communities and/or localities and transforming them, investing them with new values and affiliating them to expertise and reconfiguring relations of exclusion and power as they are reverberated across the social landscapes. It is this which holds the greatest promise for transforming Indonesia's patriarchal gender ideology in public governance. The countries in Southeast Asia are diverse in population, culture, social stratification system, governance system, political system, legal system and public administration system. Nonetheless, the Southeast Asian countries have their similarities in their legacy of colonialism, international engagement and dependency, international pressures, risings of religious groups and anti-secularization of government, the rise of democracy and the rise of discourse on participative democracy and gender mainstreaming (as opposed to simply mainstream democratization based on representative democracy).

The country's experience suggested that Indonesian women engaged with the nation's political and governance system through a variety of constructive and transformative manners: through female candidacy campaigns which impacted other party candidates and election systems (as in the case of Kofifah Indar Pariwansa Indonesia's Social Minister), through concerted activism and networking efforts in order to influence peace, reconstruction and make a difference (as in the case of Tri Rismaharini - the Mayor of the City of Surabaya), to combat discriminatory identity politics (as in the case of Megawati Sukarnoputri - Indonesia's former president), the challenges of religious fundamentalisms and discriminatory gender ideologies (as in the case of Ratna Sarumpaet - Indonesia's Human Rights Activist). In recruiting public servants, house of representative members, political party members and members of the judiciary branch, the Government of Indonesia set quotas and budgets for women's participation while taking into account heterogeneity across groups and social structures and the differing intra-gender access to support structures and resources necessary to ensure women's political citizenship and to enable their political participation. Indonesian women's roles in politics and governance is expected to become a catalyst for democracy, plurality and gender inclusion through President Joko Widodo's Nawa Cita Policy by (i) achieving a critical mass to implement critical policies in favor of gender progressive transformation (e.g. all Indonesian political parties within the House of Representatives are required to have $30 \%$ of its members to be women), (ii) ensuring citizenship rights and agency for voters, political aspirants and activists to access and shape the state to demand, ensure and defend interests and rights relating to women (e.g. political education, political socialization and political recruitments by political parties are embedded within women's organizations (Pendidikan Kesejahteraan Keluarga, Pendidikan Usia Dini, Pengajian Ibu Ibu, Nahdlatul Aisyiyah Organization, Ikatan Ibu Ibu, Ikatan Istri, Ikatan Profesi, Ikatan Perempuan, etc), women's religious schoolings (pesantren and madrasah), women's self-help groups (arisan and koperasi), (iii) instilling an egalitarian political culture and a gender equal vocabulary in political arenas while allowing voice to diverse actors and groups (e.g. providing a safe place and niche for political communication and political empowerment of women through local political parties, local dialects and gender sensitive approaches), (iv) creating an equity oriented rules of the game and institutional arrangements for selection, recruitment and interest aggregation and setting women's machineries, gender quotas and gender mainstreaming mechanisms in the heart of decision making and political processes (e.g. Islamic political parties such as PAN, PKS and PPP are at the forefront in prioritizing women and in initiating and developing gender friendly political recruitment processes while socially rewarding women for participating as members in their parties). This paper aims to analyze the challenges and opportunities for Indonesian women to actively participate in the public sphere as leaders and decision makers, taking into account the ontological underpinnings which shape the country's political ideology and political systems and their roles in promoting the third space for gender equality and inclusive governance. 


\section{Where should we start? The theory}

Theory of mainstream democracy focuses on the need for wide ranging participation and equal opportunity for representative democracy in the executive, legislative and judicial branches. Nonetheless, theory of mainstream democracy does not incorporate issues of race relations, class relations, gender relations, patriarchy, women as second/third class citizens, under representation of women in politics and governance. Theory of mainstream democracy neglects the presence of women's movements, the power of the voice, women's empowerment at the grass root level, women's agenda for political and government representation and women's political engagement which led to space for participation in politics and governance. Theory of mainstream democracy also neglects women's participation in politics which opened up other pathways for other minorities and the marginalized to participate and given a voice and attention. Much of political philosophy takes gender as given, either ascribing it to nature or ignoring it altogether. Historical events which unfolded in the twentieth century relating to racism and the civil rights movements, disintegration of nation states and the harboring of displaced citizens, political oppression and non-extractive democracy, ethnic warfare and human rights protection, religious fundamentalisms and security measures and acute global economic disparity and (dis)economies of scale have brought gender issues and gender injustices to the forefront of national and global institutions, rendering it to the attention of the global community since resolving the aforementioned issues also require mitigating gender injustices and the protection, incorporation and empowerment of women, children and the marginalized others. Deepening our understanding of the interplay and influence of those multiple factors and the ways gender interacts with other axes of social disadvantage, such as race, disability and class is clearly important to the project of advancing gender (in) justice. Hence, theory of mainstream democracy requires a refocus to incorporate concepts relating to gender injustices and women's empowerment and protection. Political philosophy, the epistemological underpinning of the theory of mainstream democracy, has harbored debates relating to gender issues and gender injustices due to their pertinence in today's highly volatile global political landscape. Current debates in political philosophy about gender do not question liberalism's egalitarian plateau, which affirms that justice requires treating people as equals. Rather, they concern the means and ends of gender justice, including the legitimacy of arrangements that, while seemingly arising on this egalitarian plateau, instantiate inequalities and the appropriate means for rectifying those inequalities that are deemed to be unjust. Through an ethnographic analysis of Indonesian women's participation in politics and governance, this paper incorporates the concepts of power, authority, civic participation and institutionalized democracy found within political philosophy and the theory of mainstream democracy and discusses them with regard to women's empowerment and women's participation as leaders and decision makers in the country's public sphere.

\section{Research Methods}

Using ethnography and qualitative inquiry as generally described by Denzin (1998), the research is an inquiry of the challenges and opportunities for women's participation as leaders and decision makers in Indonesia's public sphere, namely in government departments, political parties, the house of representatives and the judiciary. Ethnography "is an approach to field research that emphasizes providing a very detailed description of a different culture from the viewpoint of an insider in that culture in order to permit a greater understanding of it" (Neuwman 2003: 534). The unique nature of ethnography lies in its ability to provide detailed accounts of social interactions within small scale settings and its ability to reveal the rules people use to construct, maintain and transform their everyday social reality. In this research the pertinence of the ethnographic method lies in its ability to disclose the social and political constructions of the ecological landscape and the natural resources found within the case study sites. The importance of ethnography also lies in its ability to disclose the social practices which create, maintain and transform power relations associated with gender advancements. As the research examines the "rules" for constructing social reality and common sense within the field settings, including how these rules are applied, maintained and transformed in the face of power relations, the use of ethnography is important. Qualitative inquiry is adopted to enrich knowledge of the field settings and provide a "thick description of the specifics" (Geertz 1973: 17). An important aspect of qualitative research is the 
researcher's ability to follow and understand research subjects as they interact with others in the communities in which they live. The lived experience of research subjects are examined to gain a better understanding of social actions and decision making processes. Qualitative inquiry aims to describe and understand ordinary events in their natural settings, as opposed to studying events in contrived and invented settings (Herda 1999). The research holds a number of interpretive assumptions (Harmon 1986; Lee 1998). The research assumes the absence of a single perspective and the presence of multiple and incomplete subjectively derived realities which coexist. As well, the research assumes complex interactions and interdependence between the researcher and the subjects and phenomena being studied. In addition, there is a correlation between the subjects' perspectives and the dynamic patterns of reciprocity and power relations found within the social landscape. Lastly, the research assumes that through reflection and a heightened learning capacity groups and individuals have social and political opportunities for advancing gender equality as leaders and decision makers in the public sphere. The case study approach is incorporated into the research due to a number of reasons. The research aims to acquire in-depth, detailed and complex understanding of people in their natural setting, thus case study is relevant to the research. In addition, due to its capacity to contextualize social research within dynamic and complex setting, case study can provide an inclusive picture of the myriad social, cultural and political elements which constitute the social and political landscapes. Case study also provides detailed insights into the research subjects and their environment, contributing to our understanding of complex gender relations and power relations which can offer change and transformations. Research informants were selected through purposive sampling. In purposive sampling the issues and contentions which arose at the field site were used to determine the research subjects that were invited for interviews. Taking account the need for triangulation, individuals are invited from various groups and background for in-depth interviews. The categories of research informants who were invited to participate, along with their numbers in each of the categories, are depicted in Table 1.

Table 1: Categories of research informants from Indonesia

\begin{tabular}{|c|c|c|c|}
\hline Research informants & $\begin{array}{l}\text { Number of } \\
\text { informants } \\
\text { interviewed }\end{array}$ & Research informants & $\begin{array}{l}\text { Number of } \\
\text { informants } \\
\text { interviewed }\end{array}$ \\
\hline $\begin{array}{l}\text { Members of House of } \\
\text { Representatives at the Provincial } \\
\text { Level in Yogyakarta }\end{array}$ & 2 & $\begin{array}{l}\text { Members of the Judiciary at the } \\
\text { National Level in Jakarta }\end{array}$ & 2 \\
\hline $\begin{array}{l}\text { Members of House of } \\
\text { Representatives at the Provincial } \\
\text { Level in Banten }\end{array}$ & 2 & $\begin{array}{l}\text { Members of House of } \\
\text { Representatives at the National } \\
\text { Level in Jakarta }\end{array}$ & 5 \\
\hline $\begin{array}{l}\text { Members of House of } \\
\text { Representatives at the Provincial } \\
\text { Level in Jakarta }\end{array}$ & 2 & $\begin{array}{l}\text { Head of Women's Empowerment } \\
\text { Department at the Ministry of } \\
\text { Women's Empowerment in } \\
\text { Jakarta }\end{array}$ & 1 \\
\hline Members of PAN Political Party & 2 & $\begin{array}{l}\text { Members of Women's } \\
\text { Organizations (Aisyiah, Ikatan } \\
\text { Perempuan, Ikatan Profesi, PKK) }\end{array}$ & 4 \\
\hline $\begin{array}{l}\text { Member of PKS Islamic Political } \\
\text { Party }\end{array}$ & 2 & $\begin{array}{l}\text { Gender Equality Activist from a } \\
\text { National NGO in Jakarta }\end{array}$ & 2 \\
\hline $\begin{array}{l}\text { Member of PPP Islamic Political } \\
\text { Party }\end{array}$ & 2 & $\begin{array}{l}\text { Civil Servants from the Ministries } \\
\text { in Jakarta }\end{array}$ & 3 \\
\hline Member of PDIP Political Party & 2 & Academicians and Researchers & 2 \\
\hline
\end{tabular}

Data collection was conducted through participant observations, in-depth and biographical interviews, and the compilation of secondary data. In participant observation "the researcher immerses him or herself in the social locality for an extended period of time whilst observing behavior, asking questions, and listening to conversations both between others and with participants" (Bryman 2001: 506). In conducting in-depth 
interviews I used un-structured but thematically focused interviews to understand how social phenomena and their meaning are constructed and perceived by the diverse social actors. In biographical interviews the data collected is in the form of stories and events surrounding the subjects' lives (Bryman 2001). The biographical approach advocates pluralism, relativism and subjectivity (Lieblich 1998). Primary data was collected through the use of participant observations, in-depth interviews and auto-biographical interviews. Adoption of the above methods stemmed from the need to acquire detailed accounts of the social and political phenomena associated with gender inequality and gender inclusion. Data collection was conducted from January to August 2015 in Jakarta, Indonesia, Yogyakarta, Indonesia and Banten, Indonesia. Data collection was conducted through woman and/or social organizations, political parties, the House of Representatives and the Judiciary at the national and provincial levels, government departments within the country's provinces and ministries in Indonesia's capital, Jakarta. The following analytical sequences are used for analyzing and assessing every narrative and/or text contained within the primary data (Fetterman 1989; Neuwman 2003). First, the texts obtained from the interviews and the daily notes taken by the researcher are coded. The coding process involves the categorizing of texts into key ideas to explain what happens within the texts. Next, I compared data and contexts across the interviews to accentuate and explain the specific and unique. This is necessary for analyzing the divergence and convergence in perspectives and social practices. Subsequently, through repeated iterations I move from vague ideas and concrete details in the data to complex and comprehensive analyses of the issues. In addition, these concrete details are also used to acquire new insights on facilitating social responsiveness, deliberative participation and inclusive governance towards gender equality. Lastly, whilst contextualizing data within the complexity and dynamics of its environment, I attempted to discern thoughts and/or behavior patterns by comparing, contrasting and sorting the various categories which emerged from the data.

\section{Challenges and Opportunities for Indonesian Women's Participation in Politics and Governance}

Indonesia, a country governed based on the Pancasila ideology and the 1945 Constitution or Undang Undang Dasar 1945, is a multi-party republic whose parliamentary democracy is driven and guided by the people's power and the distribution of authority between the executive, legislative and judicial body of government. Pancasila and Undang Undang Dasar 1945 stipulates: (i) the need to uphold human rights and citizen's protection through integrity and social justice, (ii) the need to incorporate multiculturalism and gender differences in politics, governance and the life blood of the nation, (iii) the need for citizen's approval and consensual decision making in policy making and implementation (i.e. musyawarah mufakat) through development meetings (i.e. musrenbangs) across the various levels of government and through the approval of the majority in the House of Representatives, and (iv) the need for cooperation and collaboration (ie. gotong royong) to strengthen the nation's macro-economy through cooperatives and small and medium enterprises. The policy of equal rights, mutual respect and inclusive governance are deeply ingrained within the nation's ideology and constitution, and translated into practice through state apparatus in the form legally binding laws, decentralized public administration system, media and citizen's participation in monitoring and control and gender mainstreaming in recruiting political party members and civil servants. Considering the state as a vehicle for distributing resources and legitimizing identity and power, the state, if not accountably governed, can become the object of contention of political action and may run into the danger of being set up as a concentration of domination. It is therefore pertinent to instill checks and balances within government and political systems and to draw responsible civic participation across the social and gender divide through identity, citizenship and a sense of national membership for the unity and sovereignty of a nation. In Indonesia, democracy and democratization carry with it ideological and neo-imperial baggage in the post 2001 world. Democracy cannot stand above sexual difference but has to be re-conceptualized with the differences firmly in mind. Democracy not only deals with individuals but also with groups across social landscapes.

The status and number of female political and government actors in Indonesia is determined by socio-economic factors, institutional factors, prevailing political cultures and women's psychological factors. Effective measures for recruiting and incorporating women as leaders and decision makers in political parties and the 
legislative and executive government bodies thus far have include: (i) gender mainstreaming through laws and legislations, (ii) quotas that are set up for women's participation as members in political parties, parliaments, civil service, judiciaries and executive government departments and (iii) sustained and legally supported budgeting for ensuring women's empowerment and participation in the above institutions. In order to increase women's participation in the parliament, the GOI enacted Law No 10/Year 2008 concerning Elections for The House of Representatives at the national, provincial and regency levels of government and Law No 2/Year 2008 concerning Political Parties which stipulates that each political parties must reserve $30 \%$ of their seat in the House of Representatives for women. This law also stipulates that in order for political parties to receive funding from the state, they must fulfill the requirement that $30 \%$ of their members in The House of Representatives at the national, provincial and regency level be women and must set aside a portion of their budget for expenses relating to the political empowerment and political inclusion of women and minority groups. Moreover, Article 8 of Law No 10/Year 2008 also stipulates that in order for political parties to be able to participate in the presidential election, $30 \%$ of its members must be women. Hence, the stipulation that $30 \%$ of political party members must be women is ingrained in the establishment, management, enlistment and representation of political parties within the House of Representatives. Subsequent to Suharto's downfall in 1998, NGOs advocating for gender equality has pushed for affirmative action to empower women and incorporate them in strategic public positions to influence decision making and public policy. Moreover, Article 4 in Law No 8/Year 2012 also stipulates that the National, Provincial and Regency Level Electoral Commissions must publish the number of women participating as candidates in the election for legislative members through print and electronic media. This aids in mitigating geographical disparity in women's participation in politics and governance. Moreover, these concerted efforts have doubled the number of women as members of political parties and members of the House of Representatives at the regency, provincial and national level of government since the year 2008 .

The recruitment process for becoming a political party member include: (i) aptitude test (i.e. for Islamic political parties this also includes examination involving religious subject matters), (ii) psychological examination, (iii) a test of loyalty and a test of the candidate's sustained participation and contribution to the political party. The recruitment process for becoming a legislative member in the House of Representatives through the political parties include: (i) nominating potential candidates from current and available members, (ii) candidate selection process by senior party officials within teams, (iii) candidates that are chosen within the district and regency level are tested in the regency level for selection for the regency level House of Representatives whereas candidates that are chosen within the provincial level are tested in the provincial level for selection for the provincial level House of Representatives and so on. Challenges described by women for becoming a political party member and a member of the House of Representatives related to the country's patriarchal gender ideology include: (i) characteristics of those women elected/to be elected are different from those of the electorate as a whole: women will always be in the 'wrong' position, doing the 'wrong' thing, saying the 'wrong' thing, fighting for the 'wrong' thing, and above all, offending the right people, (ii) political systems marked by androcentrism and misogyny, (iii) political violence, (iv) ideological polarization and patriarchal gender ideology, (v) sexist and hostile political climate in parliaments, (vi) hostile socio-political culture and patriarchal gender ideology, and (vii) assertive political stance, directness and outspoken-ness among women jeopardize women's reputation, their voter appeal and their capacity to make and influence policies. Effective measures that are mentioned by respondents to address the above challenges include instilling diplomacy, negotiating and brokering a form of participative democracy in the context of present political ideologies from sub-national to national level politics and governance. Megawati Soekarnoputri is an Indonesian woman who shows her concern for politics. She represents the voice of Indonesian women in planning and implementation of governance. Megawati Soekarnoputri is the first female President in Indonesia. When she became President of the Republic of Indonesia, Megawati broke the patriarchal ideology that has been entrenched in Indonesia. Megawati was a member of the House of Representatives and then became a Chairman of the PDI-P Party. According to Megawati, politics and education cannot be separated. Politics produces educational systems, and education influences political life. This he conveyed when she received her Honoris Causa (Dr. HC) Doctorate 
Degree from Universitas Negeri Padang (UNP) for her contribution as President with the issuance of Law No.20/Year 2003 on National Education System.

Challenges described by women for becoming a political party member and a member of the House of Representatives related to the bureaucratic apparatus include: (i) barriers for women to enter the pool of eligible voters, the roster of eligible candidates in political parties or tap the full potential of their mandates, (ii) lack of resources to finance a campaign or to finance necessities of a successful mandate, (iii) most successful women candidates come from elite families and/or political dynasties, (iv) elite negotiations and top down approaches which prevent upward career mobility and women from occupying strategic and leadership positions. Effective measures that are mentioned by respondents to address the above challenges include instilling grass root social and political empowerment and mentoring at the local regency and provincial level for political recruitment through mentors, regional political party branches and local religious and secular organizations where women participate in. Challenges described by women for becoming a political party member and a member of the House of Representatives related to identity and ethnicity include: (i) the intricate dynamics of the dominant ethnic and identity politics in which women political officials have to operate, (ii) community, religious and political leaders impose restrictions on women's mobility, dress code, space, roles, (iii) Sharia Islamic Law, and (iv) the need for women to be accompanied by chaperones or mahrams when going out. Effective measures that are mentioned by respondents to address the above challenges include establishing political education, civic education and multicultural education to young boys and girls at schools and universities from the national level to the regional and local levels. Another successful female figure in Indonesian politics is Rieke Diah Pitaloka. Rieke managed to break the perception of women in politics. Rieke can prove that she can become a member of a political party (i.e. PDIP) and become a member of The House of Representatives in the period 2009 - 2014. In her activities at the House's Commission IX, Rieke focuses on the health and welfare of Indonesian society. Rieke is one of the members of the Special Draft Committee of the Social Security Administering Agency (BPJS) which is part of the National Social Security System (SJSN). Rieke Dyah Pitaloka also established a foundation named "Yayasan Pitaloka" which is engaged in literature and civic duty. On March $3^{\text {rd }} 2013$ the results of the Election of Governor - Vice Governor of West Java (i.e. Cagub-Cawagub) pair number five consisting of Rieke-Teten was ranked two out of five with a total acquisition of 5,714,997 votes or 28.41 percent of the total valid votes. According Rieke, the world of politics also requires the art of living the role of a good politician, where one must use the heart in perceiving every aspiration of the society. According to her, politics should be based on the art in order to be able to feel it using the heart.

With regard to public servants within government departments, executive departments and the judiciary, respondents noted that the challenge for women include upward career mobility, acquiring strategic and leadership positions for decision making and policy making and acquiring opportunities to lead government projects within and across sectors and government levels. These challenges are attributed to (i) gender role prescriptions and honor conceptions, (ii) old boys' networks and informal meetings, (iii) man's veto-power both in the domestic and public sphere and (iv) exclusionary and/or non-inclusive agenda setting. Women who are leaders noted that there is limited space for pluralism and pluralistic interest aggregation in policy drafting and policy making. This narrative shows that women are cultural markers for conflicting societal visions and value systems and that effort to incorporate women in the political and governance system should not stand above sexual differences but rather should take into account those differences.

\section{Theoretical Discussions}

Promoting women's participation requires organization and institutionalization. The need to organize and institutionalize suggests the need for politics; but politics can never be expected to conform to the mandates set out within acts of governance and institutionalization (Dyrberg 1997: 203): 
The political is in the social as an ordering and organizing principle, which means that the social as the underlying framework of consensus cannot be prior to the political, or beneath it, enveloping it, restricting it or conditioning it.

A number of consequences follow from the account above. The social and political will always exceed given regime structures since it cannot be reduced to the interests of the formal and legal institutions where they arise (Dyrberg 1997). Promoting civic participation and collective action requires organization and institutionalization. The need to organize and institutionalize suggests the need for politics; but politics can never be expected to conform to the mandates set out within acts of governance and institutionalization (Dyrberg 1997: 203):

The political is in the social as an ordering and organizing principle, which means that the social as the underlying framework of consensus cannot be prior to the political, or beneath it, enveloping it, restricting it or conditioning it.

A number of consequences follow from the account above. The social and political will always exceed given regime structures since it cannot be reduced to the interests of the formal and legal institutions where they arise (Dyrberg 1997). As well, a political power struggle does not allow for collective action to be "conceptualized in terms of the consensual decision making approach" (Dyrberg 1997: 204). As well, social and political processes "cannot be defended on procedural grounds alone since these grounds are themselves in need of being grounded in political values" (Dyrberg 1997: 204). Concurrent with Ostrom's remark in Commons in the New Millenium (2003), there is the need to develop an understanding of the kinds of social and structural relationships that need to be developed for participative engagement and reciprocity in sustainable governance to be surmounted.

In The Means of Correct Training Foucault (1999) argued that power and politics are not solely within the domain of the state. Foucault analyses power from the inside and below, "taking its point of departure from the infinitesimal mechanisms of power" (Foucault 1999: 97). In Indonesia power relations and power struggles are found within social and government institutions at various levels. These multiple sources of power add to the complexity in decision making. Hence, there is "the need to grasp how the plethora of local politics and power coalesces into general ones and become embedded in various institutions through practice" (Dyrberg 1997: 106). The ethnographic narratives from Indonesia suggest that the reality of on-ground governance can undermine democracy and equitable consensus. As well, the case of Indonesia also suggests that local contests, competing timelines and social dynamics all influence a person's perception of ecological goods and their instruments of governance.

In The Circular Structure of Power: Politics, Identity and Community, Dyrberg (1997) noted that political representation and political processes shape identity construction by bridging the structural disparity between individual and citizen, private and public, and state and society. As a result, power strategies may become embedded within informal institutional settings (Dyrberg 1997). The influence which institutional settings have on social relations among groups and individuals is then projected through "relations of representation and regulatory institutional network which cut across the state and civil society distinction" (Dyrberg 1997: 192). In Indonesia, political processes and political representation contribute greatly in shaping and altering the social constructions surrounding the gender equality and women's empowerment. Through political processes, the social constructions of women and the landscapes are (re)configured into local institutions. These institutional settings in turn influence groups and individuals through the constraints and enablers they impose.

Dyrberg (1997: 192) noted that "the crystallization of political authority is made possible through the capacity to enforce social relations under the expression of representation". In Indonesia, political authority is crystallized through relations of representation and the disciplinary institutional network. Nonetheless, Indonesia's social and political landscape is also marked by systematization of differences over "what is ethically acceptable and unacceptable" (Dyrberg 1997: 206). Over long time spans these differences may converge in distance (Dyrberg 1997: 206). According to Dyrberg (1997: 206), although "aggregation and integration mutually condition each 
other", they "should be seen in relation to this systematization of differences, which in a democracy is continuously negotiated".

Gender equality and women's protection cannot be expected to sustain itself on the basis of the disciplinary institutional network and/or adherence to common values alone. Identification and engagements are always marked by struggles and resistance as well as alignments and adaptations. As well, the consequences of the disciplinary institutional network are not as pervasive and profound as that imagined by proponents of critical theory (Adorno 1982; Marcuse 1988; Horkheimer 2002). Conflicts and contentions among the cultivators suggest differences and negotiations, and this can open the space for promoting communicative exchange, social capability and gender responsiveness.

\section{Conclusions and Recommendations}

The concept of citizenship and deliberative participation in the country's present political thinking involves the protection, empowerment and incorporation of women. Barriers for women's participation in politics and government include lack of resources to finance a campaign or to finance necessities of a successful mandate, public private divide of social space (women as mothers, wives, daughters, daughter in laws), political violence, ideological polarization and patriarchal gender ideology, gender role prescriptions and honor conceptions, sexist and hostile political climate in parliaments and government departments and the lack of psychological empowerment among Indonesian women. Best practices which enable and facilitate women's participation in politics and government in Indonesia include gender mainstreaming through laws and legislations, quotas for women in political parties, parliaments, civil service, judiciaries, executive government departments, sustained and legally supported budgeting for ensuring women's empowerment and participation, grass root social and political empowerment at the local regency level for political recruitment through mentors, regional political party branches and local religious and secular organizations, political education to young girls at schools and universities from the national level to the regional and local levels, diplomacy, negotiating and brokering a form of participative democracy in the context of present political ideologies from sub-national to national level politics and governance. From a psychological standpoint, best practices from Indonesia suggest that women's chances of succeeding in politics depend on their beliefs in their capabilities. These women also structure situations for them in ways that bring success and avoid placing people in situations prematurely where they are likely to fail often. They measure success in terms of self-improvement rather than by triumphs over others.

\section{References}

Acheson, J. 1994, Anthropology and Institutional Economics, Lanham Publications, University Press of America, Maryland, pp. $1-419$.

Adorno, T. 1982, Against Epistemoloy: A Metacritique. Studies in Husserl and the Phenomenological Antimonies, Basil Blackwell, Oxford, London, pp. 5 - 8.

Agrawal, A. (2008). Environmentality: Technologies of Government and the Making of Environmental Subjects. London, Oxford University Press.

Ashforth, B. (1998). Becoming: How Does the Process of Identification Unfold. Identity in Organizations: Building Theory through Conversations. D. Whetten. London, Sage Publications.

Baba, H. (1994). "The Commitment to Theory." The Location of Culture: 19-39.

Batterbury, S., Bebbington, Anthony, Lewis, David, Olson, Elizabeth (2003). Of Texts \& Practices: Organizational Cultures \& the Practice of Empowerment in World Bank Funded Programs. Order \& Disjuncture: The Organization of Aid \& Development, SOAS, Russell Square, London.

Beck, U. (1999). Individualization and "Precarious Freedom": Perspectives and Controversies of a Subject Oriented Sociology. Contemporary Social Theory. A. Elliott. Malden, Massachussetts, Blackwell Publisher. I: 156-169.

Beck, U. (2000). What is Globalization? London, United Kingdom, Polity Press. 
Beilin, R. (2004). Connecting to Social Theory to Social Research. S. i. S. R. M. Class. Melbourne, Australia. Bhaba, H. (1994). "The Commitment to Theory." The Location of Culture: 19-39.

Bourdieu, P. (1991). Language \& Symbolic Power. Cambridge, UK, Polity Press.

Bryman, A. (2001). Social Research Methods. New York, Oxford University Press.

Calhoun, C. (1995). Critical Social Theory: Culture, History \& the Challenge of Difference. Cambridge, Massachusetts.

Coleman, J. (1990). Foundations of Social Theory. Cambridge, Harvard University Press.

Cortazzi, M. (1993). Narrative Analysis. London, The Falmer Press.

Crotty, M. (1998). The Foundations of Social Research: Meaning and perspective in the research process. St. Leonards, Australia, Allen \& Unwin Pty. Ltd.

Denzin, N. (1998). The Landscape of Qualitative Research: Theories \& Issues. Thousand Oaks, California, Sage Publications.

Dyrberg, T. B. (1997). The Circular Structure of Power: Politics, Identity, Community. New York, New York, Verso Publishing.

Elliot, A., Ed. (1999). Contemporary Social Theory. Malden, Massachussetts, Blackwell Publishers Inc.

Etzioni, A., Ed. (1968). The Active Society: A Theory of Societal and Political Processes. London, CollierMcMillan Limited.

Etzioni, A. (2004). The Common Good. Malden, Massachussetts, Polity Press.

Fararo, J. C. T., Ed. (1992). Rational Choice Theory: Advocacy and Critique. Key Issues in Sociological Theory. New York, Sage Publications.

Fetterman, D. (1989). Ethnography: Step by Step. London, Sage Publications.

Foucault, M. (1999). The Means of Correct Training. Contemporary Social Theory. A. Elliott. Malden, Massachussetts, Blackwell Publishers Inc. I: 97-107.

Friedberg, M. C. E. (1977). Actors \& Systems: The Politics of Collective Action. Chicago, The University of Chicago Press.

Friedmann, J. (1992). Empowerment: The Politics of Alternative Development. Oxford, UK, Blackwell.

Fuchs, S. (1992). The Professional Quest for Truth: A Social Theory of Science \& Knowledge. New York, State University of New York Press.

Geertz, C. (1973). Thick Description: Towards an Intrepretive Theory of Culture. Interpretation of Cultures. New York, Basic Books Inc.

Gershenson, C. (2005). "How can We Think the Complex." 2006, from www.vub.ac.be/CLEA.

Giddens, A. (1981). A Contemporary Critique of Historical Materialism. London, MacMillan Press, Ltd.

Habermas, J. (1987). Lifeworld and System: A Critique of Functionalist Reason. Boston, Massachusets, Beacon Press.

Habermas, J. (1997). The Theory of Communicative Action: Reason and Rationalization of Society. Cambridge, Polity Press.

Hardin, G. (1968). "The Tragedy of the Commons." Science 162: 1243-1248.

Harmon, M. (1986). Organization Theory for Public Administration. Boston, Massachusetts, Little Brown \& Company.

Harvey, D. (1996). Justice, Nature \& the Geography of Difference, Blackwell Publishers.

Herda, E. (1999). Research Conversations and Narrative. London, Praeger.

Holub, R. (1992). Antonio Gramsci. Beyond Marxism and Postmodernism. London, Routledge.

Honneth, A. (1999). Patterns of Intersubjective Recognition: Love, Rights and Solidarity. Contemporary Social Theory. A. Elliot. Malden, Massachussets, Blackwell Publishers. i: 184-196.

Horkheimer, M. (2002). Dialectic of Enlightenment. Stanford, California, Stanford University Press.

Hoy, D. C., Ed. (1986). Foucault: A Critical Reader. New York, Basil Blackwell. 
Kiros, T. (1985). Towards the Construction of a Theory of Political Action: Antonio Gramsci Consciousness, Participation \& Hegemony. New York, University Press of America.

Lacan, J. (1999). The Mirror Stage as Formative of the Function I as Revealed in Psychoanalytic Experience. Contemporary Social Theory. A. Elliott. Malden, Massachussets, Blackwell Publishers Inc. I: 61-67.

Law, J. (2003) Making a Mess with Method. Centre for Science Studies Lancaster University Volume, DOI:

Law, J. (2004). After Method. Mess in Social Science Research. London, Routledge Publishing.

Lee, T. (1998). Using Qualitative Methods in Organizational Research. Thousand Oaks, California, Sage Publications.

Lesser, E., Ed. (2001). Knowledge \& Social Capital: Foundations \& Applications. Boston, Massachusetts, Butterworth Heinemann.

Leuwis, C. (1993). "Towards a Sociological Conceptualization of Communication in Extention Science." Sociologica Ruralis XXXIII: 281-305.

Lieblich, A. (1998). Narrative Research: Reading, Analysis \& Interpretation. London, Sage Publications.

Light, A., Ed. (1998). Social Ecology after Bookchin. Democracy \& Ecology. A Guilford Series. London, The Guilford Press.

Lynch, M. (1993). Scientific Practice and Ordinary Action: Ethnomethodology andSocial Studies of Science. Melbourne, Cambridge University Press.

Lyotard, J. F. (1979). The Postmodern Condition: A Report on Knowledge. Manchester, Manchester University Press.

Marcuse, H. (1988). Critical Theory \& The Promise of Utopia. Massachusetts, Bergin \& Garvey Publishers, Inc.

Meszaros, I. (1989). The Power of Ideology. London, Harvester Wheatsheaf.

Mohan, G. S., Kristian (2000). "Participatory Development \& Empowerment: The Dangers of Localism." Third World Quarterly 21(2): 247-268.

Mumby, D., Ed. (1993). Narrative \& Social Control: Critical Perspectives. Sage Annual Reviews of Communication Research. London, Sage Publications.

Neuwman, L. (2003). Social Research Methods: Qualitative \& Quantitative Methods. Boston, Massachussetts, Pearson Education Inc.

Ostrom, E. (1990). Governing the Commons: The Evolution of Institutions for Collective Actions. Cambridge, Cambridge University Press.

Ostrom, E. (1993). Institutional Arrangements \& the Commons Dillemma. Rethinking Institutional Analysis \& Development: Issues, Alternatives \& Choices. D. F. H. P. Vincent Ostrom. San Francisco, California, Institute for Contemporary Studies Press: 101-127.

Ostrom, E. (1994). Neither Market Nor State: Governance of Common Pool Resources in the Twenty First Century. Washington, D.C., International Food Policy Research Institute.

Ostrom, E. (1995). Constituting Social Capital and Collective Action. Local Commons \& Global Interdependence: Heterogeneity \& Cooperation in Two Domains. R. K. E. Ostrom. London, Sage Publications. I: $125-161$.

Ostrom, E. (2000). "Collective Action and the Evolution of Social Norms." Journal of Economic Perspectives 14(3): 137 - 158.

Ostrom, E., Ed. (2003). The Commons in the New Millenium. Challenges and Adaptations. London, MIT Press.

Ostrom, E., Ed. (2007). Understanding Knowledge as a Commons. From Theory to Practice. Cambridge, MIT Press.

Ostrom, E. a. (2005). The Samaritan's Dilemma: The Political Economy of Development Aid. New York, Oxford University Press.

Pels, D. (2003). Unhastening Science: Autonomy \& Reflexivity in the Social Theory of Knowledge. Liverpool, Liverpool University Press.

Plumwood, V. (2002). Environmental Culture: The Ecological Crisis of Reason. London, Routledge Publications. 
Rappaport, J. (1994). Community Narratives \& Personal Stories: An Introduction to Five Studies Cross Level Relationships.

Rhoads, S. (1985). The Economists's View of the World. Melbourne, Cambridge University Press.

Rohdewohld, R. (1995). Public Administration in Indonesia. Melbourne, Montech Pty Ltd.

Rourke, F. E., Ed. (1986). Bureaucratic Power in National Policy Making. Boston, Little Brown and Company.

Sabatier, P., Ed. (1981). Effective Policy Implementation. Lexington, Massachusetts, Lexington Books.

Sarbin, T. R. (1986). The Narrative as a Root Metaphor for Psychology. Narrative Psychology: The Storied Nature of Human Conduct. T. R. Sarbin. New York, Praeger: 3-21.

Schon, D. A. (1987). Educating the Reflective Practitioner. Towards a New Design for Teaching \& Learning in the Professions. San Francisco, Jossey-Bass Publishers.

Soja, E. W. (1989). Postmodern Geographies. The Reassertion of Space in Critical Social Theory. London, Verso Publication.

Turnbull, D. (2005). Masons, Tricksters \& Cartographers: Comparative Studies in the Sociology of Scientific \& Indigenous Knowledg. London, Routledge.

Umar, R. (2003). "Pola Resistensi Kehidupan Komunitas Miskin Pedesaan." Jurnal Alumni, Januari 2003 Vol.8 No.2: 67 - 77.

Van Loon, B. (2001). Introducing Critical Theory. Melbourne, Victoria, McPherson's Printing Group.

Weick, K. (1995). Sensemaking in Organizations. London, Sage Publications.

Wenger, E. (1998). Communities of Practice: Learning, Meaning \& Identity. Cambridge, United Kingdom, Cambridge University Press.

Yin, R. K. (1984). Case Study Research: Design \& Methods. London, Sage Publications.

Zey, M., Ed. (1992). Decision Making: Alternatives to Rational Choice Models. London, Sage Publications. 